\title{
36. SEDIMENTARY MINERALOGY OF ARGILLACEOUS SEDIMENTS FROM DEEP SEA DRILLING PROJECT HOLES 436, 438A, AND 439, JAPAN TRENCH
}

\author{
Koichi Aoyagi and Toshie Kazama, Central Technical Laboratory, Japan Petroleum Exploration Co. Ltd., \\ Tokyo, Japan
}

\begin{abstract}
Mineral assemblages of DSDP Holes 436 and 438A and the upper section of Hole 439 (871.5-911.0 m sub-bottom) resemble each other and are composed of montmorillonite (probably a small portion of montmorillonite/illite mixed-layer clays), illite, chlorite, kaolinite, quartz, plagioclase, hornblende, calcite, dolomite, siderite, gypsum, pyrite, and halite. In the middle section of Hole 439 (933.5-1041.0 $\mathrm{m})$, clinoptilolite is also found. In the lower section of Hole 439 $(1077.5-1150.0 \mathrm{~m})$, montmorillonite is not confirmed, and clinoptilolite and mixed-layer illite are found. These assemblages, which also contain detrital kaolinite, are generally found in sediments from brackish-water environments. At Site 439, more than 1000 meters of sediment might have been removed by erosion at the base.
\end{abstract}

\section{INTRODUCTION}

The transformation of minerals in argillaceous sediments during diagenesis is mainly due to changes in physical factors such as overburden pressure, temperature, and chemical factors such as $p \mathrm{H}, \mathrm{Eh}$, and composition of fluids. Therefore, petrological study of mineral assemblages in sediments is very important to consideration of primary migration of petroleum hydrocarbons from source rocks (Powers, 1967; Burst, 1969; Perry and Hower, 1972; and Aoyagi and Asakawa, 1978), and also essential to analysis of origin of pores in reservoirs (Aoyagi, 1973; and others).

In the present paper, we report the mineral assemblages found in argillaceous sediments taken from DSDP Site 436 of Leg 56 and Sites 438 and 439 of Leg 57 , drilled during the Japan Trench transect. We will also explain the mineralogical and thermal properties of clay minerals found in these sediments, and discuss the environments and diagenesis of these sediments inferred from sedimentary mineralogy.

\section{SAMPLES AND METHODS OF ANALYSIS}

Core samples taken from Holes 436, 438A, and 439 are mainly composed of argillaceous sediments. Geological descriptions of these sediments were already reported by shipboard scientists of Legs 56 and 57.

Samples, 68 in total, were taken from these cores and analyzed mineralogically by means of X-ray diffractometry and DTA-TG. Each sample was dried in an oven at a temperature lower than $60^{\circ} \mathrm{C}$ for 24 hours and then crushed by agate mortar into a powder finer than 250 mesh.

X-ray diffractometry was performed under the following conditions: $\mathrm{CuK} \alpha$ radiation with a nickel filter, $30 \mathrm{KV} / 52 \mathrm{~mA}, 1^{\circ}$ beam slit and 0.4 to $0.5 \mathrm{~mm}$ detection slit. Goniometric speed was $1 \% / \mathrm{min}$, and chart speed was $10 \mathrm{~mm} / \mathrm{min}$.

The mineral composition of each powdered sample was qualitatively analyzed by the X-ray diffractometer. $\mathrm{X}$-ray diffraction peaks of each mineral measured are 001 for montmorillonite, illite, and kaolinite, 002 for chlorite and plagioclase, 020 for clinoptilolite and gypsum, 101 for quartz, 104 for calcite, dolomite, and siderite, 110 for hornblende, and 200 for pyrite and halite. Treatments with hydrochloric acid and ethylene glycol were done for the identification of these minerals. This method of analysis is explained by Oinuma and Kobayashi (1966) and Aoyagi (1967). The existence of illite-montmorillonite mixed-layer minerals is inferred from the width of the $17 \AA$ peak of glycolated samples, and is confirmed by the tailing of intensities at the lower angle side, associated with the $10 \AA$ peak of illite.

The experimental conditions of DTA-TG were as follows: platinium sample holder (macro- and microtype), alpha-alumina standard sample and platinel thermo-couples. Mean heating rate was $5^{\circ} \mathrm{C} / \mathrm{min}$ using micro-type sample holder, and $10^{\circ} \mathrm{C} / \mathrm{min}$ using macrotype sample holder.

\section{RESULTS}

\section{Mineral Composition}

Mineral compositions of each sample analyzed by $\mathrm{X}$-ray diffractometer are shown in Table 1. Relative amounts of constituent minerals were estimated from the representative peak intensities (counts per second).

Figure 1 illustrates the representative X-ray diffractograms of argillaceous sediments from Hole 439. Diffractograms of untreated powdered samples are indicated on the left side, samples treated with ethylene 
TABLE 1

Mineral Composition (counts per second) and $d$ Spacing $(\AA)$ of Montmorillonite and Montmorillonite-Illite Mixed-Layer Clay*

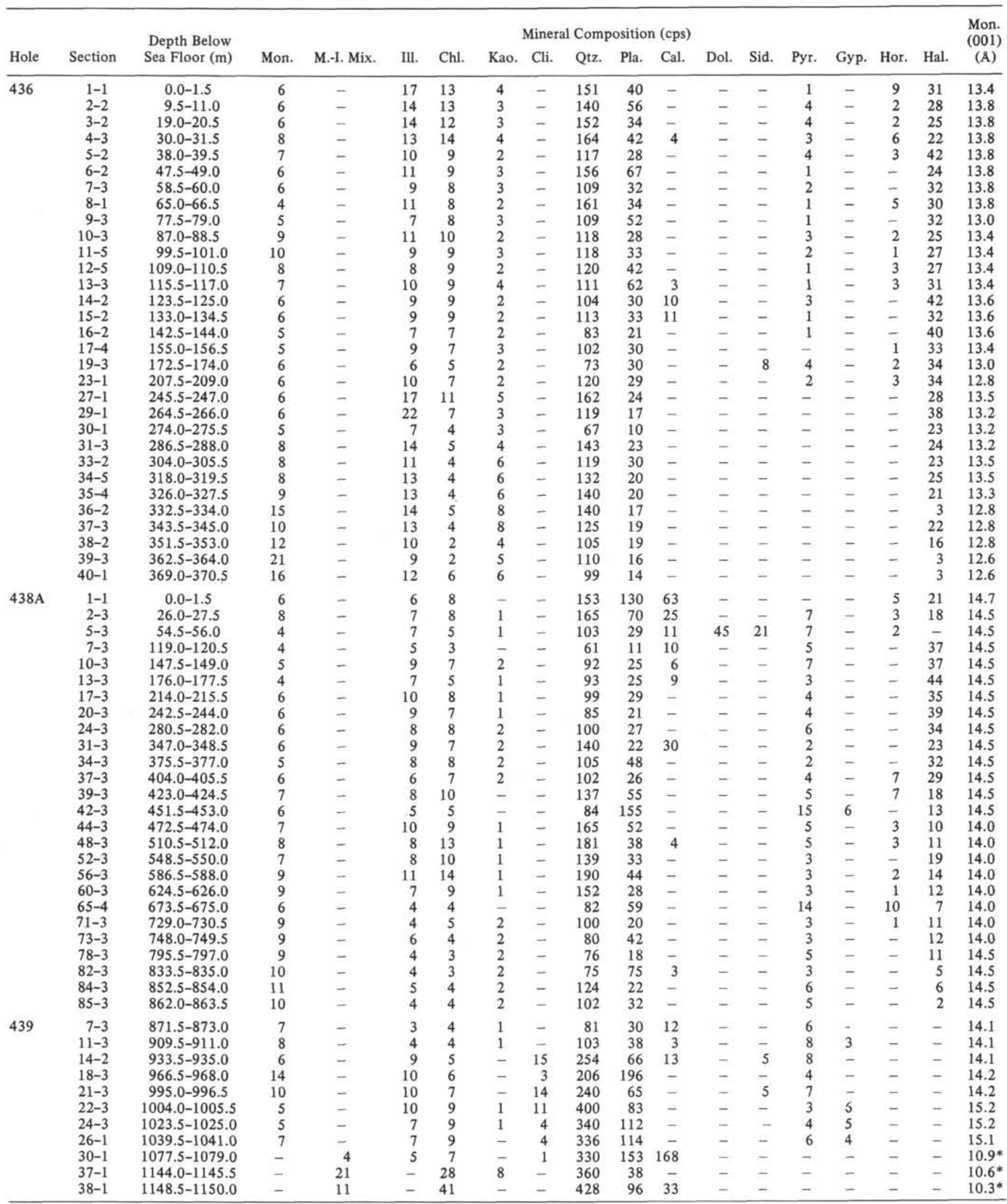

${ }^{*} d$ spacing $(\AA)$ of M.-1. Mix. represented by $10 \AA$ peak with tailed reflections on the lower angle side. Mon. $=$ montmorillonite; M.-I. Mix. $=$ montmorilloniteillite mixed-layer clay; Ill. = illite; Chl. = chlorite; Kao. = kaolinite; Cli. = clinoptilolite; Qtz. = quartz; Pla. = plagioclase; Cal. = calcite; Dol. = dolomite; Sid. $=$ siderite Pyr. $=$ pyrite $;$ Gyp. $=$ gypsum $;$ Hor. $=$ hornblende Hal. $=$ halite . 


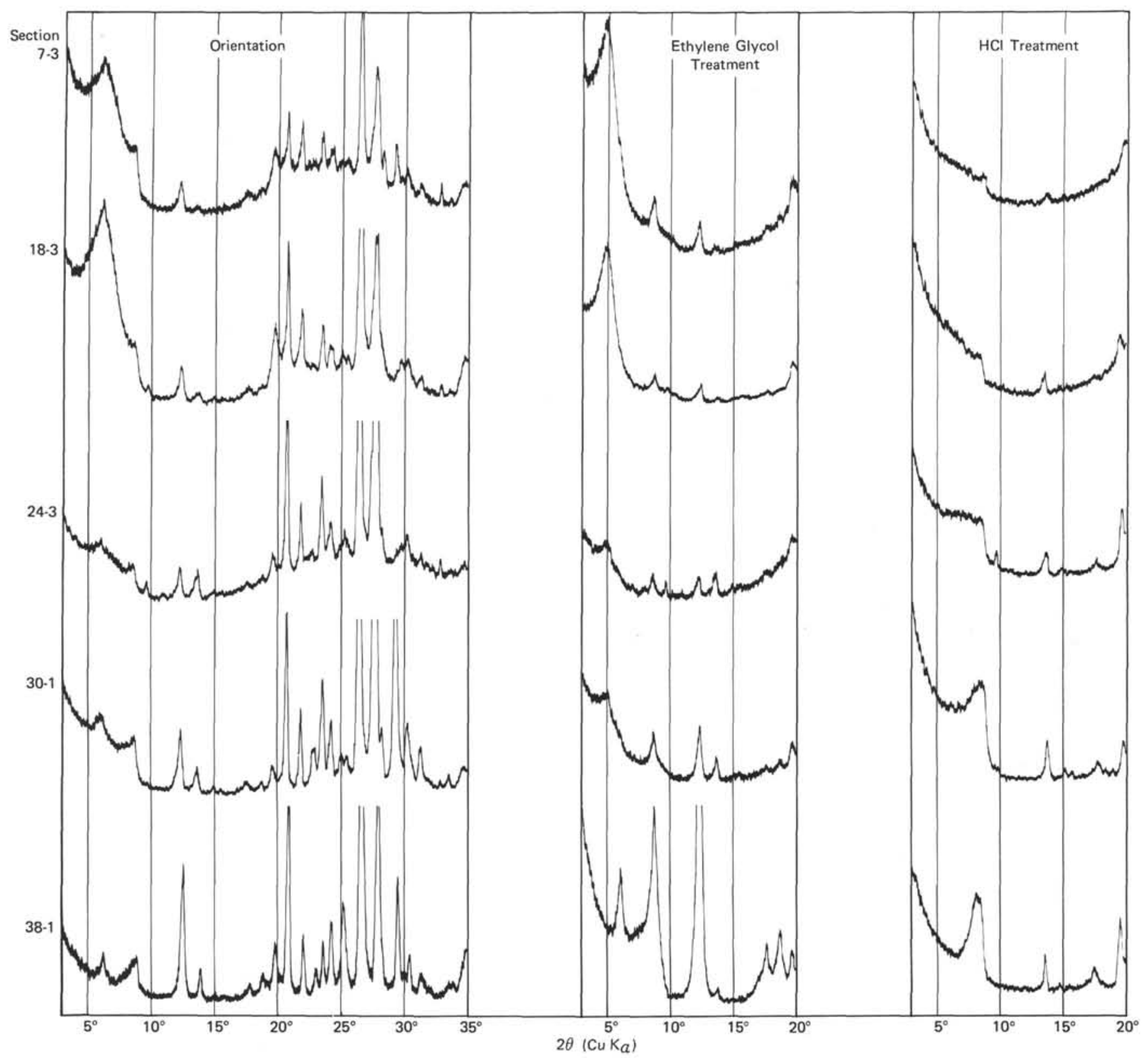

Figure 1. Representative X-ray diffractograms of sediments from Hole 439.

glycol in the middle, and samples treated with hydrochloric acid on the right.

From the X-ray diffractograms of treated and untreated powdered samples, the following facts are clear:

1. The chlorite peaks were nearly all destroyed by treatment with hydrochloric acid. This suggests that the chlorite belongs to the trioctahedral type.

2. Small $7 \AA$ peaks remain after treatment with hydrochloric acid. This indicates the existence of a small amount of kaolinite.

3. Extremely broad peaks, compared with those of illite and chlorite, overlap with the 001 peak of chlorite. After treatment with hydrochloric acid, the broad peak is observed as a continuous reflection in a range between 10 and $15 \AA$. This profile may be described as a $10 \AA$ peak with a long tail of intensity on the long-spacing side. The spacings as shown by these broad peaks nearly coincide with the 001 peak of chlorite in the samples from Holes $438 \AA$ and 439 (14.7 $\AA$ in Hole $438 \AA$ and $14.5 \AA$ in Hole 439 on the average). However, broad peaks occur which are slightly separated from the 001 peak of chlorite in the samples from Hole $436(13.4 \AA$ average). After treatment with ethylene glycol, the broad peak observed in untreated sample is nearly transferred to the $17 \AA$ peak, which is broad with medium to strong intensities. Although the spacings as indicated by the 17 A peak vary in a small range, they mostly indicate fully expanded states, as shown by $17.5 \AA$ for the samples from Hole 438A, $17.9 \AA$ for Hole 439 , and $17.6 \AA$ for Hole 436 (averages).

The broad peak may be conclusively assigned to montmorillonite, mainly accompanied by small amounts 
of mixed-layer illite and montmorillonite. Variation of the basal spacings of montmorillonite within the range 14 to $13 \AA$, which is smaller than that of usual montmorillonite (15.4 $\AA$ ), may be due to the modification by interlayer cations. The mixed-layer minerals are in small quantity and may contain large amounts of excess montmorillonite layers (up to $80 \%$ ). It is difficult to estimate the amount of montmorillonite distinct from the small amount of mixed-layer mineral. In the present study, therefore, the amount of mineral estimated from the broad peak was ascribed to montmorillonite.

4. In the X-ray diffractograms of the samples from the lower section of Hole 439 (1077.5-1150.0 m), broad montmorillonite peaks are not found, while a $10 \AA$ peak with a "tail" of intensity on the long-spacing side occurs. The tailed reflection was lost after treatment with ethylene glycol, probably because it was transferred to an extremely broad peak by expansion. The spacing of the $10 \AA$ is in the range 10.3 to $10.5 \AA$. This type has been called "degraded illite" by Brown (1954); in the present sample it is considered to be a mixed-layer mineral of illite and montmorillonite, with a large proportion of illite layers.

\section{Mineral Assemblages}

Minerals identified in sediments from Holes 436 and 438A are montmorillonite, illite, chlorite, kaolinite, quartz, plagioclase, calcite, dolomite, siderite, pyrite, gypsum, hornblende, and halite. Dolomite, siderite, and gypsum are generally rare. Mineral compositions of each sediment closely resemble each other.

From the mineral compositions of each sediment from Hole 439, three mineral assemblages can be recognized. The upper mineral assemblage, which ranges from 871.5 to 911.0 meters below sea floor, closely resembles those of Holes 436 and 438A. The middle assemblage, which ranges from 933.5 to 1041.0 meters, is composed of montmorillonite, illite, chlorite, kaolinite, clinoptilolite, quartz, plagioclase, calcite, siderite, pyrite, and gypsum; calcite is generally rare. The lower assemblage, which ranges from 1077.5 to 1150.0 meters, is composed of montmorillonite-illite mixed-layer mineral, illite, chlorite, kaolinite, clinoptilolite, quartz, plagioclase, and calcite; illite and clinoptilolite are rare.

\section{Thermal Properties}

Representative DTA-TG curves (using macro-type sample holder) of selected samples from Hole 439 are illustrated in Figure 2. In the TG curves, weight loss occurs in two steps: one between 60 and $130^{\circ} \mathrm{C}$, and the other between 500 and $600^{\circ} \mathrm{C}$. The former is due to the loss of adsorption water, including interstitial water between grains and interlayer water of montmorillonite. The latter is due to the removal of hydroxyl water from clay minerals in the present samples. Corresponding to these steps, weak endothermic peaks are observed in DTA curves. Weak exothermic peaks between 400 and $500^{\circ} \mathrm{C}$ may be due to the decomposition of pyrite. A strong endothermic peak between 800 and $900^{\circ} \mathrm{C}$ in the sample from Section 30-1 is due to the decomposition of calcium carbonates (probably calcite).

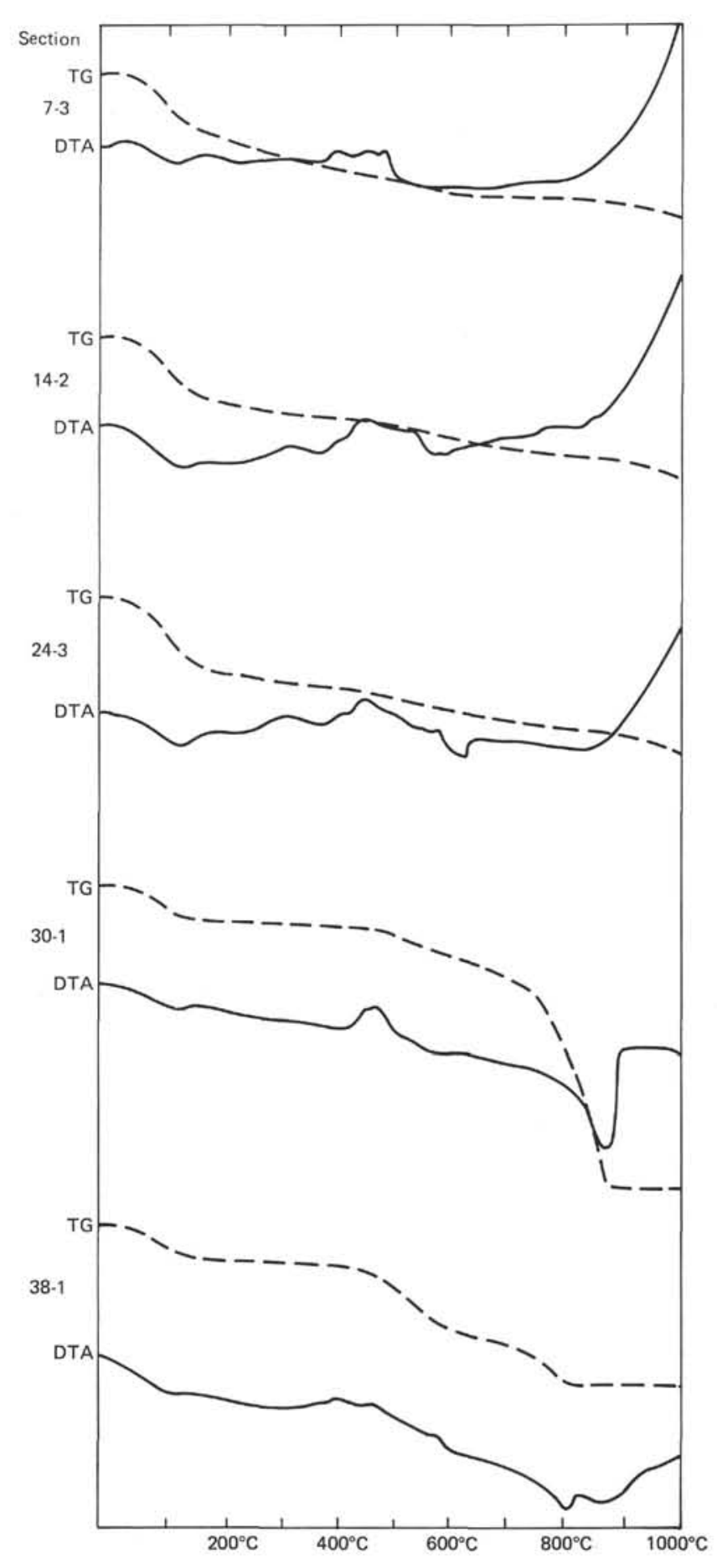

Figure 2. Representative DTA-TG curves (using macrotype sample holder in air atmosphere) for selected samples from sections of Hole 439: Section 7-3, $112.0 \mathrm{mg}$; $14-2,150.4 \mathrm{mg} ; 24-3,171.3 \mathrm{mg} ; 30-1,249.8 \mathrm{mg} ; 38-1$, $209.0 \mathrm{mg}$.

From the results of DTA-TG (using micro-type sample holder), the weight-loss ratio at $125^{\circ} \mathrm{C}$ of the representative sediments from Holes 436, 438A, and 439 are presented in Table 2 . The weight losses mainly represent adsorption water in clay particles. Weight-loss ratios of the samples from Sections 30-1 and 38-1 of Hole 439 are 
TABLE 2

Weight-Loss Ratio at $125^{\circ} \mathrm{C}$ from the Results of DTA-TG

\begin{tabular}{|c|c|c|c|}
\hline \multirow[b]{2}{*}{ Hole } & \multicolumn{2}{|r|}{ Sample } & \multirow[b]{2}{*}{$\begin{array}{c}\text { Weight-Loss Ratio } \\
\text { at } 125^{\circ} \mathrm{C} \\
(\%)\end{array}$} \\
\hline & Section & $\begin{array}{l}\text { Sub-bottom } \\
\text { Depth } \\
\text { (m) }\end{array}$ & \\
\hline 436 & $\begin{array}{r}1-1 \\
5-2 \\
9-3 \\
15-2 \\
19-3 \\
23-1 \\
29-1 \\
35-4 \\
40-1\end{array}$ & $\begin{array}{c}0.0-1.5 \\
38.0-39.5 \\
77.5-79.0 \\
133.0-134.5 \\
172.5-174.0 \\
207.5-209.0 \\
264.5-266.0 \\
326.0-327.5 \\
369.0-370.5\end{array}$ & $\begin{array}{l}4.96 \\
6.78 \\
6.64 \\
5.00 \\
2.50 \\
3.44 \\
3.23 \\
4.91 \\
5.58\end{array}$ \\
\hline $438 \mathrm{~A}$ & $\begin{array}{r}2-3 \\
24-3 \\
48-3 \\
71-3 \\
85-3\end{array}$ & $\begin{array}{c}26.0-27.5 \\
280.5-282.0 \\
510.5-512.0 \\
729.0-730.5 \\
862.0-863.5\end{array}$ & $\begin{array}{l}2.59 \\
3.33 \\
3.34 \\
3.62 \\
3.63\end{array}$ \\
\hline 439 & $\begin{array}{r}7-3 \\
14-2 \\
24-3 \\
30-1 \\
38-1\end{array}$ & $\begin{array}{c}871.5-873.0 \\
933.5-935.0 \\
1023.5-1025.0 \\
1077.5-1079.0 \\
1148.5-1150.0\end{array}$ & $\begin{array}{l}2.62 \\
2.21 \\
1.59 \\
0.07 \\
0.07\end{array}$ \\
\hline
\end{tabular}

about 0.1 per cent, while those of other samples from Hole 436, Hole 438A, and the upper part of Hole 439 range from 1.6 to 6.8 per cent. This means that there are great differences between the mineralogy of these two kinds of samples, corresponding actually to the difference between montmorillonite and mixed-layer mineral.

\section{DISCUSSION}

Two clay mineral facies are found in the sediments analyzed. The first is recognized in sediments from Hole 436, Hole 438A, and the upper part of 439 (871.5-1041.0 $\mathrm{m}$ sub-bottom) and is composed of montmorillonite, illite, chlorite, and kaolinite. The other is found in sediments from the lower part of Hole 439 (1077.5-1150.0 $\mathrm{m})$ and is composed of montmorillonite-illite mixedlayer mineral, illite, chlorite, and kaolinite. The former is identified as clay mineral facies of sub-type $\mathrm{Ib}$ and the latter as IIb (Aoyagi et al., 1975). Sub-type Ib is generally found in argillaceous rocks of brackish-water environments, having undergone little or no diagenesis. Sub-type IIb is an authigenic-clay-mineral facies which has been transformed from sub-type Ib.

Aoyagi and Kazama (1978) reported the temperature and pressure necessary for the diagenetic transformation of clay minerals, zeolites, and silica minerals in the Cretaceous and Tertiary argillaceous sediments of Japan. For clay minerals, a pressure of at least $900 \mathrm{~kg} / \mathrm{cm}^{2}$ and a temperature of $104^{\circ} \mathrm{C}$ are necessary for the transformation from montmorillonite to montmorillonite-illite mixed-layer mineral and $920 \mathrm{~kg} / \mathrm{cm}^{2}$ and $137^{\circ} \mathrm{C}$ for mixed-layer mineral to illite. Transformation from kaolinite to other minerals requires much higher pressure and temperature than does that from montmorillonite to mixed-layer clay. For zeolites, $330 \mathrm{~kg} / \mathrm{cm}^{2}$ and $56^{\circ} \mathrm{C}$ are required for the transformation from volcanic glass to clinoptilolite, $860 \mathrm{~kg} / \mathrm{cm}^{2}$ and $116^{\circ} \mathrm{C}$ for clinoptilolite to heulandite and(or) analcite, and $930 \mathrm{~kg}$ / $\mathrm{cm}^{2}$ and $138^{\circ} \mathrm{C}$ for heulandite and(or) analcite to laumontite and(or) albite. For silica minerals, $250 \mathrm{~kg} / \mathrm{cm}^{2}$ and $45^{\circ} \mathrm{C}$ are necessary for the transformation from amorphous silica to low cristobalite, and $660 \mathrm{~kg} / \mathrm{cm}^{2}$ and $69^{\circ} \mathrm{C}$ for low cristobalite to low quartz.

As shown in Figure 3, the first appearance of montmorillonite-illite mixed-layer mineral is at 1077.5 meters sub-bottom in Hole 439, and clinoptilolite is firstly recognized at 933.5 meters.

Measured temperatures at the sea floor and the bottom of Hole 439 (1157.5 m sub-bottom) are 1.2 and $26.0^{\circ} \mathrm{C}$, respectively. Corrected true bottom-hole temperature by the formula of Tanaka and Sato (1977) is $33.7^{\circ} \mathrm{C}$. Therefore, the true geothermal gradient in this well is calculated as $2.81^{\circ} \mathrm{C} / 100 \mathrm{~m}$.

From the geothermal gradient of the well, actual temperatures at depths of 933.5 and 1077.5 meters are calculated as 27.4 and $31.5^{\circ} \mathrm{C}$, respectively. These temperatures are much lower than those necessary for the neoformations of clinoptilolite and mixed-layer mineral. Since, however, there is evidence for such neoformation in the samples investigated, this indicates either that the geothermal gradient during the period of neoformation of these minerals was much higher than that at the present time, and (or) that there has been significant erosion of sediment above the subtype IIb facies at the bottom of Hole 439.

The proper geothermal gradient for the neoformation of these minerals ranges from 5.9 to $9.5^{\circ} \mathrm{C} / 100 \mathrm{~m}$. These values, however, we believe are too high for the paleogeothermal gradient of the Japan forearc region. Therefore, it is reasonable to consider that erosion might have occurred, since these sediments were formed in shallow water, and an unconformity at the base of the Oligocene and(or) Miocene could be expected. The calculated stratigraphic deficiency ranges from 1000 to 2600 meters based on the necessary temperatures.

There is one further interpretation of the origin of the mixed-layer mineral found in the lower section of Hole 439. Generally speaking, mixed-layer minerals of illite and montmorillonite can be formed as weathering products of illite during the predepositional stage. Weathered illite is usually capable of potassium fixation. When weathered illite is included in sediments as detrital minerals, the degree of potassium fixation clearly increases with burial depth, even at relatively shallow levels (Perry et al., 1976). Mixed-layer minerals originating from weathered illite are usually heterogeneous in layer proportions.

Furthermore, such mixed-layer minerals can occur in shallower to considerably deeper levels, and also in young as well as old sediments, as long as an acidic chemical environment is maintained in sediments after deposition. Brown et al. (1977) reported that degraded illite occurs in a mixed-layer state or as dioctahedral vermiculite in deltaic sediments of Middle Pennsylvanian age. Therefore, it is possible that the mixed-layer minerals in the lower section of Hole 439 are detrital. In 


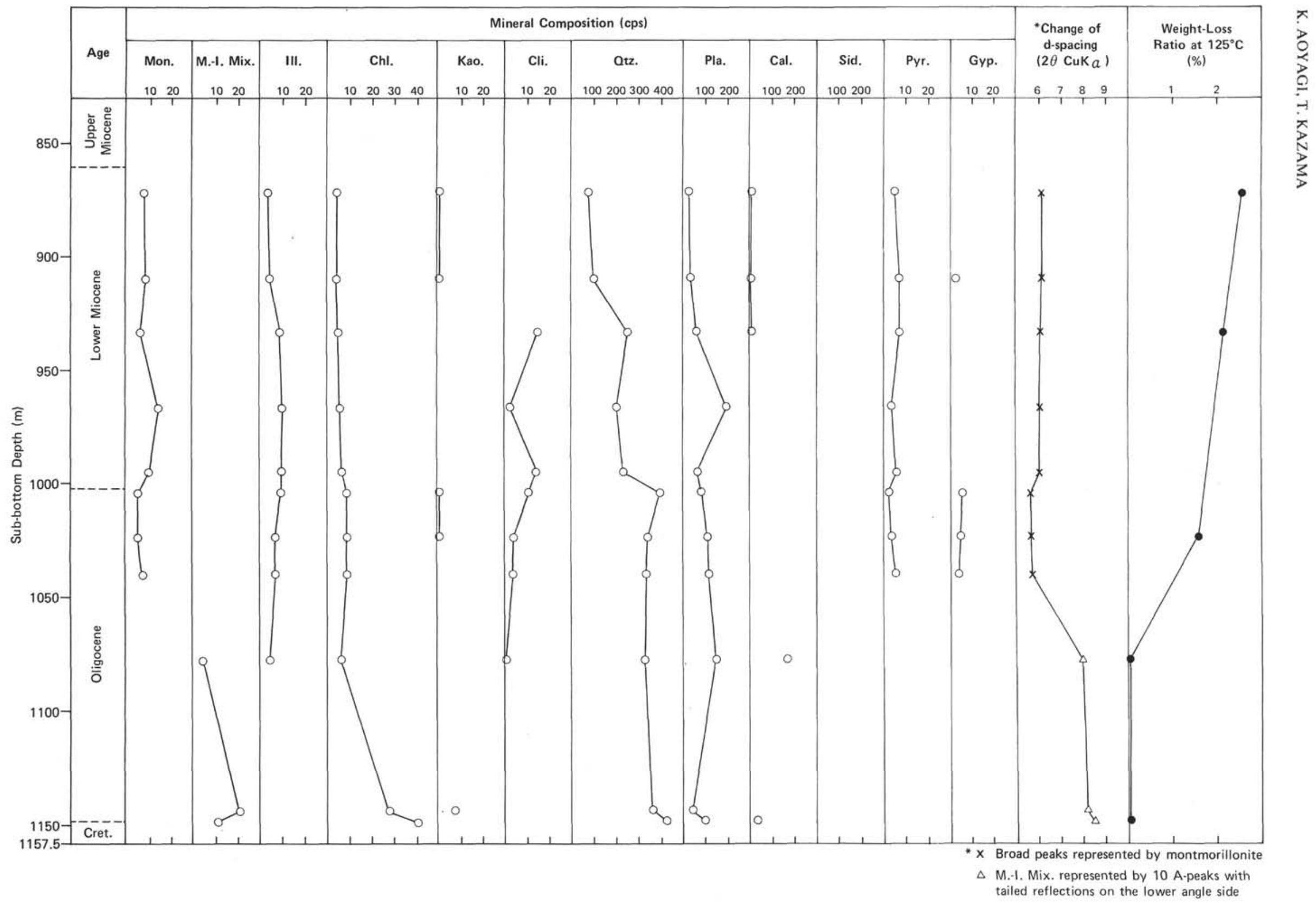

Figure 3. Changes of mineral composition (cps), d spacing $(2 \Theta \mathrm{CuK \alpha})$ of montmorillonite and montmorillonite-illite mixed-layer mineral, and weight loss ratio at $125^{\circ} \mathrm{C}$, Hole 439 . Abbreviations as in Table 1. 
this case, it may not be anomalous that the minerals occur at about 1000 meters in association with clinoptilolite. In this connection, it is noted that montmorillonite particles are extremely fine, as indicated by their extremely broad X-ray peak, compared with those of illite and chlorite. This suggests that the montmorillonite may have been crystallized from a colloidal state, and the basal spacings, which are slightly smaller than those of typical montmorillonite, might be due to potassium fixation.

\section{ACKNOWLEDGMENTS}

We would like to thank Japan Petroleum Exploration Company for permission to complete this special work. Dr. Toshio Sudo, emeritus professor of Tokyo University of Education, and Dr. Hakuyu Okada, professor of Shizuoka University, read the manuscript and made important comments. Misses Toshie Takamasa and Sumi Kaneko of our laboratory drafted the figures and tables. We thank them very much.

\section{REFERENCES}

Aoyagi, K., 1967. Mineralogical study of sedimentary rocks in the oil fields of Japan by the X-ray diffraction method, and its application to petroleum geology, pt. 1. Clay Sci., 3. 37-54.

1973. Petrophysical approach to origin of porosity of carbonate rocks in middle Carboniferous Windsor Group, Nova Scotia, Canada. Am. Assoc. Petrol. Geol. Bull., 57, 1692-1702.
Aoyagi, K., and Asakawa, T., 1978. Primary migration theory of petroleum and its application to petroleum exploration. IAS Abstracts, 1, 25-26.

Aoyagi, K., and Kazama, T., 1978. Transformational changes of clay minerals, zeolites and silica minerals during diagenesis. IAS Abstracts, 1, 27-28.

Aoyagi, K., Kobayashi, N., and Kazama, T., 1975. Clay mineral facies in argillaceous rocks of Japan and their sedimentary petrological meanings. Proc. Internat. Clay Conf., Mexico City, 101-110.

Brown, G., 1954. Degrading illite. Nature, 173, 644.

Brown, L. F., Bailey, S. W., Cline, L. M., and Lister, J. S., 1977. Clay mineralogy in relation to deltaic sedimentation patterns of Desmoinesian cyclothems in Iowa-Missouri. Clays Clay Mineral., 25, 171-186.

Burst, J. F., 1969. Diagenesis of Gulf Coast clayey sediments and its possible relation to petroleum migration. $\mathrm{Am}$. Assoc. Petrol. Geol. Bull., 53, 73-93.

Oinuma, K., and Kobayashi, K., 1966. Quantitative study of clay minerals in some recent marine sediments and sedimentary rocks from Japan. Clays Clay Mineral., 14, 209-219.

Perry, E. A., Jr., Gieskes, J. M., and Lawrence, J. R., 1976. $\mathrm{Mg}, \mathrm{Ca}$ and $\mathrm{O}^{18} / \mathrm{O}^{16}$ exchange in the sediment-pore water system, Hole 149, DSDP. Geochim. Cosmochim. Acta, 40, 413-423.

Perry, E. A., Jr., and Hower, J., 1972. Late stage dehydration in deeply buried pelitic sediments. Am. Assoc. Petrol. Geol. Bull., 56, 2013-2021.

Powers, M. C., 1967. Fluid-release mechanism in compacting marine mudrocks and their importance in oil exploration. Am. Assoc. Petrol. Geol. Bull., 51, 1240-1254.

Tanaka, T., and Sato, K., 1977. Estimation of subsurface temperature in oil and gas producing areas, northeast Japan. J. Jap. Assoc. Petrol. Tech., 42, 229-237. 